\title{
Effect of Vitamin E Supplementation on Immunity against Newcastle Disease Virus in T-2 Toxin Challenged Chickens
}

\author{
M. WEBER ${ }^{1}$, J. FODOR $^{2}$, K. BALOGH ${ }^{1,2}$, L. WÁGNER $^{3}$, M. ERDÉLYI ${ }^{1}$, M. MÉZES ${ }^{1}$
}

\author{
${ }^{1}$ Department of Nutrition, Szent István University, Gödöllő, Hungary \\ ${ }^{2}$ Research Group of Animal Breeding and Hygiene of the Hungarian Academy of Science, Faculty of Animal \\ Science, Kaposvár University, Kaposvár, Hungary \\ ${ }^{3}$ Institute of Animal Science, Georgikon Faculty of Agriculture, Veszprém University, \\ Keszthely, Hungary
}

Received May 28, 2007

Accepted November 15, 2007

\begin{abstract}
Weber M., J. Fodor, K. Balogh, L. Wágner, M. Erdélyi, M. Mézes: Effect of Vitamin E Supplementation on Immunity against Newcastle Disease Virus in T-2 Toxin Challenged Chickens. Acta Vet. Brno 2008, 77: 45-49.

The effect of T-2 toxin contaminated feed $\left(2.35 \mathrm{mg} \cdot \mathrm{kg}^{-1}\right)$ and/or vitamin E supplementation in drinking water $\left(10.5 \mathrm{mg} /\right.$ animal $\cdot$ day $\left.^{-1}\right)$ for 14 days on the haemagglutination inhibition titres against Newcastle disease virus was investigated in repeatedly vaccinated (on 23 days of age) broiler chicken. The animals were divided into four groups: (1) control; (2) treated with vitamin E; (3) fed a T-2 toxin contaminated feed; (4) fed a T-2 toxin contaminated diet and treated with vitamin E. Blood samples were taken on days 7 and 14 of the experiment for determination of sera titres and vitamin E content, liver samples were also taken on the same days for vitamin E determination. It was found that haemagglutination titres increased in comparison to the controls as an effect of vitamin E supply and also a low dose T-2 toxin challenge. The combination of both treatments showed some synergistic effect. The utilization of vitamin E decreased by the feeding of T-2 toxin contaminated diet, particularly in the liver.
\end{abstract}

T-2 toxin, vitamin E, Newcastle disease, haemagglutination inhibition, chicken

Trichothecenes are secondary fungal metabolites originating especially from Fusarium molds that contaminate almost all crops before harvest, having started from contaminated seeds with continued growth until harvesting. The occurrence of Fusarium is spreading all over the world and the mycotoxin-producing conditions vary yearly according to climatic conditions. Much literature has been published, and opposing observations have been reported, concerning the immunosuppressive and alleviating effects of the trichothecenes, such as the T-2 toxin (Pestka and Bondy 1994), because they accumulate mainly in the thymus and spleen (Lafarge-Frayssinet et al. 1990) and inhibit protein synthesis (Ueno et al. 1973) and also induce DNA single-strand breaks (LafargeFrayssinet et al. 1981).

The effect of the T-2 toxin on the immune response was investigated in poultry species but the results were sometimes contradictory. No significant effect of the T-2 toxin was observed on antibody production at a concentration of up to $1 \mathrm{mg} \cdot \mathrm{kg}^{-1}$ feed in chicken (Sklan et al. 2001) and turkey (Sklan et al. 2003), also in turkey poults and chicken fed a T-2 toxin contaminated feed even at a concentration of $10 \mathrm{mg} \cdot \mathrm{kg}^{-1}$ (Richard et al. 1978). In respect of haemagglutination inhibition antibody titre to Newcastle disease, the results showed that the T-2 toxin at $1.25 \mathrm{mg} \cdot \mathrm{kg}^{-1}$ body weight (approximately $12.5 \mathrm{mg} \cdot \mathrm{kg}^{-1}$ feed) did not affect the titre in the $4^{\text {th }}$ week of age (Hossain et al. 1987); on the contrary, a 3 $\mathrm{mg} \cdot \mathrm{kg}^{-1} \mathrm{~T}-2$ toxin contaminated feed reduced the titre in a five-week experiment (Raju and Devegowda 2002). On the other hand, in our previous experiment $2.35 \mathrm{mg} \cdot \mathrm{kg}^{-1} \mathrm{~T}-2$ toxin increased the haemagglutination titre for up to 14 days after vaccination, but decreased during the same period using $4.18 \mathrm{mg} \cdot \mathrm{kg}^{-1} \mathrm{~T}-2$ toxin (Weber et al. 2006a).

Address for correspondence:

Miklós Mézes

Department of Nutrition, Szent István University

H-2103 Gödöllö, Páter Károly u. 1, Hungary
Phone: +36 28410735

Fax: +3628410804

Email: Mezes.Miklos@mkk.szie.hu

http://www.vfu.cz/acta-vet/actavet.htm 
Animals can be commonly treated against chronic affection of mycotoxins with vitamin supplementation (Böhm 2000). Most trichothecene mycotoxins impair the antioxidant status of chickens (Surai et al. 2004) and also the utilisation of vitamin E (Weber et al. 2007) and several natural (vitamin E, carotenoids, chlorophyll and its derivatives, phenolics and selenium) and synthetic (butylated hydroxyanisole and butylated hydroxytoluene) compounds with antioxidant properties seem to be potentially very efficacious in protecting against the toxic effects of mycotoxins (Atroshi et al. 2002).

\section{Materials and Methods}

The experimental animals were ROSS 308 broiler cockerels (initial age: 23 days) divided into four groups of 20 birds in each. With the exception of the control and vaccinated groups, chicken feed was contaminated with the T-2 toxin $\left(2.35 \mathrm{mg} \cdot \mathrm{kg}^{-1}\right)$ and fed for 14 days. There is no official regulation in the European Union for a maximum T-2 toxin content allowed in a feed but a guideline limit of $0.5 \mathrm{mg} \cdot \mathrm{kg}^{-1} \mathrm{~T}-2$ toxin is proposed (Eriksen and Pettersson 2004). In the present experiment the T-2 toxin contamination of the feed was $2.35 \mathrm{mg} \cdot \mathrm{kg}^{-1}$, which was much higher than the maximum tolerated dose level.

The partially purified toxin preparation was dissolved in acetone and then sprayed onto the compound feed (100 $\mathrm{ml} / 50 \mathrm{~kg}$ of feed). The T-2 toxin was produced on maize by Fusarium tricinctum, strain NRRL 3229 (Agricultural Research Service Culture Collection, National Center for Agricultural Utilization Research, Peoria, IL). The extraction and purification of the toxin were carried out according to Burmeister (1971). The T-2 toxin content of the feed was measured by the HPLC technique (Central Veterinary Institute, Budapest). The amounts of related trichothecenes, HT-2, T-2 triol and T-2 tetraol, were under the detection limit.

The animals were obtained from a commercial hatchery and vaccinated against Newcastle disease virus with attenuated Newcastle disease vaccine in the hatchery using the same product as the vaccinated groups received in the form of eye drops (Nobilis ${ }^{\circledR}$ ND Clone 30, Intervet International bv, Boxmeer) on day 1 of the experiment according to the producer's instructions.

Vitamin E was supplemented in drinking water at the dose of $10.5 \mathrm{mg} /$ bird daily (Esvex Oral Solutio, Veterinaria Spa.) and calculated based on the average water consumption.

The four groups (Table 1) in the experiment were as follows: (1) vaccinated control; (2) vitamin E supplemented and vaccinated group; (3) vaccinated group receiving a T-2 contaminated feed; (4) vitamin E supplemented and vaccinated group fed a T-2 toxin contaminated diet.

Table 1. Applied treatments in the different groups

\begin{tabular}{|c|c|c|c|}
\hline Group & $\begin{array}{c}\mathrm{T}-2 \text { toxin } \\
\left(\mathrm{mg} \cdot \mathrm{kg}^{-1} \text { feed }\right)\end{array}$ & $\begin{array}{c}\text { Vitamin E supply } \\
(\mathrm{mg} / \text { animal/day })\end{array}$ & Vaccination \\
\hline 1 & - & - & + \\
\hline 2 & - & 10.5 & + \\
\hline 3 & 2.35 & - & + \\
\hline 4 & 2.35 & 10.5 & + \\
\hline
\end{tabular}

Blood samples were taken on days 7 and 14 of the experiment from the cubital vein, and blood serum was analysed using haemagglutination inhibition (HI) test against Newcastle disease according to Balla (1986). The vitamin $\mathrm{E}$ content was measured in blood serum and liver using the HPLC method (McMurray et al. 1980)

The average haemagglutation titres were calculated with a geometrical mean using MS Excel 7.0 software, and statistically evaluated based on the $\log _{2}$ transformation of the dilution rate as described by Balla (1986) and the ANOVA analysis carried out using Statistica 4.5 (Statsoft Inc., 1993) software.

\section{Results and Discussion}

Live weight, weight gain and feed consumption did not differ significantly among the experimental groups (data not shown). This result is different than some previous findings, when a marked decrease of the growth rate was found as an effect of the T-2 toxin (Leeson et al. 1995), yet using the same amount of T-2 toxin no significant changes were found in the production traits in our previous experiments (Weber et al. 2006a, b). These differences may be due to the different amount of the toxin in the feed and the duration of treatment. There were also no significant differences in the relative weight of the bursa of Fabricius among the groups (data not shown), which was also described as a detrimental effect of the T-2 toxin in poultry (Leeson et al. 1995).

The vitamin E content in blood plasma (Table 2) increased significantly following the 
vitamin E treatment in the vaccinated group, did not differ from the vaccinated control in the T-2 toxin challenged group, and the combination of the T-2 toxin challenge with vitamin E supply resulted in a further increase. In our previous study (Weber et al. 2007), $\mathrm{T}-2$ toxin had the opposite effect, namely it lowered the vitamin E content in blood plasma up to day 14 of treatment. It means that vaccination against Newcastle disease eliminates the negative effect of the T-2 toxin on the vitamin E content in blood plasma, possibly due to changes in the protein content and composition - IgG formation - of blood plasma. Contrary to the findings in blood plasma in the case of liver (Table 3), vaccination did not have a positive effect on the vitamin E content in the T-2 toxin challenged group with vitamin $\mathrm{E}$ supplementation but the vitamin $\mathrm{E}$ content in the liver remained on the control level in the T-2 toxin challenged and vitamin E supplemented group. That result supports our previous results (Weber et al. 2007) when a T-2 toxin challenge did not cause a marked decrease in the vitamin E content of liver as was found in a previous study (Dvorska and Surai 2001), however, the T-2 toxin challenge decreased the utilisation of supplemental vitamin $\mathrm{E}$. The possible cause of the lower rate of vitamin $\mathrm{E}$ utilisation in the liver is the increased free radical formation in the liver as was found in some previous studies in poultry (Mézes et al. 1998; Dvorska and Surai 2001).

Table 2. Effect of T-2 toxin and vitamin E supplementation on the vitamin E content of blood plasma in broiler chickens (mean $\pm \mathrm{SD})$

\begin{tabular}{|c|c|c|c|c|}
\hline $\begin{array}{c}\text { Day of } \\
\text { sampling }\end{array}$ & Vaccinated control & $\begin{array}{c}\text { Vitamin E } \\
\text { supplemented } \\
+ \text { vaccinated }\end{array}$ & $\begin{array}{c}\text { T-2 toxin } \\
\text { challenged } \\
+ \text { vaccinated }\end{array}$ & $\begin{array}{c}\text { T-2 toxin challenged } \\
+ \text { vitamin E supplemented } \\
+ \text { vaccinated }\end{array}$ \\
\hline & \multicolumn{4}{|c|}{ Vitamin E content of blood plasma $\left(\mathrm{mg} \cdot \cdot^{-1}\right)$} \\
\hline Day 7 & $17.83 \pm 5.81^{\mathrm{ab}}$ & $36.54 \pm 6.05^{\mathrm{bc}}$ & $17.69 \pm 4.24^{\mathrm{a}}$ & $47.70 \pm 7.92^{\mathrm{bc}}$ \\
\hline Day 14 & $20.73 \pm 6.91^{\mathrm{ab}}$ & $36.01 \pm 8.06^{\mathrm{bc}}$ & $17.31 \pm 1.41^{\mathrm{a}}$ & $54.20 \pm 9.92^{\mathrm{bc}}$ \\
\hline
\end{tabular}

${ }^{\mathrm{a}-\mathrm{b}}$ and ${ }^{\mathrm{a}-\mathrm{c}}$ : Different superscripts in the same raw mean significant difference at $P<0.05$ as compared to the control and the T-2 toxin challenged groups, respectively

Table 3. Effect of T-2 toxin and vitamin E supplementation on the vitamin E content of liver in broiler chickens (mean $\pm \mathrm{SD})$

\begin{tabular}{|l|c|c|c|c|}
\hline $\begin{array}{c}\text { Day of } \\
\text { sampling }\end{array}$ & Vaccinated control & $\begin{array}{c}\text { Vitamin E } \\
\text { supplemented } \\
+ \text { vaccinated }\end{array}$ & $\begin{array}{c}\text { T-2 toxin } \\
\text { challenged } \\
+ \text { vaccinated }\end{array}$ & $\begin{array}{c}\text { T-2 toxin challenged } \\
+ \text { vitamin E supplemented } \\
+ \text { vaccinated }\end{array}$ \\
\hline & \multicolumn{4}{|c|}{ Vitamin E content of blood plasma $\left(\mathrm{mg} \cdot \cdot^{-1}\right)$} \\
\hline Day 7 & $16.66 \pm 2.18^{\mathrm{a}}$ & $36.37 \pm 7.82^{\mathrm{b}}$ & $19.11 \pm 3.97^{\mathrm{ab}}$ & $17.99 \pm 6.04^{\mathrm{ab}}$ \\
\hline Day 14 & $8.47 \pm 2.50^{\mathrm{ab}}$ & $28.55 \pm 6.47^{\mathrm{bc}}$ & $7.37 \pm 4.43^{\mathrm{a}}$ & $19.04 \pm 9.77^{\mathrm{bc}}$ \\
\hline
\end{tabular}

${ }^{\mathrm{a}-\mathrm{b}}$ and ${ }^{\mathrm{a}-\mathrm{c}}$ : Different superscripts in the same raw mean significant difference at $P<0.05$ as compared to the control and the T-2 toxin challenged groups, respectively

The values of the haemagglutination inhibition titre (Table 4) showed that in the vitamin E supplemented group it was significantly higher as compared to the vaccinated T-2 toxin control group, but only on day 7. The positive effect of vitamin E on the immune functions (Bendich 1987) including antibody formation (Tengerdy 1989) is well known. Feeding the T-2 toxin contaminated feed at the dose of $2.35 \mathrm{mg} \cdot \mathrm{kg}^{-1}$ did not decrease the haemagglutination titre which was also found in our previous study (Weber et al. 2006ab). Otherwise the vitamin E supply together with the feeding of a T-2 toxin contaminated diet has additional but not significantly positive effect on the haemagglutination inhibition titre, namely antibody formation against Newcastle disease virus protein. That positive tendency was possibly caused by the inhibitory effect of vitamin $\mathrm{E}$ on stress-induced glucocorticoid response (Golub and Gershwin 1985), which eliminated the immune depressive effect of 
glucocorticoids as a physiological response to the T-2 toxin load as environmental stressor during the first week; however, that effect decreased during the second week, possibly due to the lower utilisation of vitamin $\mathrm{E}$ in $\mathrm{T}-2$ toxin challenged birds.

Table 4. Effect of vitamin E treatment and feeding T-2 toxin contaminated feed and vaccination against Newcastle disease on haemagglutination inhibition titres in blood sera of chickens

\begin{tabular}{|c|c|c|c|}
\hline \multirow{2}{*}{ Group } & \multirow{2}{*}{$\begin{array}{l}\text { Period after repeated } \\
\text { vaccination (days) }\end{array}$} & \multicolumn{2}{|c|}{ HAG titer } \\
\hline & & Geometric mean & $\log _{2}$ mean \pm SD \\
\hline $\begin{array}{l}\text { Vaccinated } \\
\text { control }\end{array}$ & $\begin{array}{r}7 \\
14\end{array}$ & $\begin{array}{r}181.02 \\
1722.16\end{array}$ & $\begin{array}{r}7.50 \pm 3.00 \\
10.75 \pm 1.50\end{array}$ \\
\hline $\begin{array}{l}\text { Vitamin E supplemented } \\
\text { + vaccinated }\end{array}$ & $\begin{array}{r}7 \\
14 \\
\end{array}$ & $\begin{array}{l}1776.27 \\
4096.00\end{array}$ & $\begin{array}{l}10.67 \pm 0.58^{b} \\
12.00 \pm 0.00\end{array}$ \\
\hline $\begin{array}{l}\text { T-2 toxin challenged } \\
+ \text { vaccinated }\end{array}$ & $\begin{array}{r}7 \\
14 \\
\end{array}$ & $\begin{array}{r}512.00 \\
4096.00 \\
\end{array}$ & $\begin{aligned} 9.00 & \pm 1.23^{\mathrm{a}} \\
12.00 & \pm 0.00\end{aligned}$ \\
\hline $\begin{array}{l}\text { T-2 toxin challenged } \\
+ \text { vitamin E supplemented } \\
+ \text { vaccinated }\end{array}$ & $\begin{array}{r}7 \\
14\end{array}$ & $\begin{array}{r}388.02 \\
2896.31\end{array}$ & $\begin{array}{r}9.25 \pm 1.50 \\
11.60 \pm 0.89\end{array}$ \\
\hline
\end{tabular}

a-b: Different superscripts in the same column on the same day of sampling mean significant difference at $P<0.05$ level

In conclusion, the results of the present study suggest that antibody formation against Newcastle disease was improved by vitamin E treatment in drinking water and was not suppressed by the short-term sublethal T-2 toxin load, particularly in combination with a high dose of vitamin E supply.

\section{Účinek doplňku vitamínu E na odolnost proti viru Newcastleské nemoci u kuřat vystavených toxinu T-2}

Byl zkoumán vliv krmení kontaminovaného toxinem T-2 $\left(2,35 \mathrm{mg} \cdot \mathrm{kg}^{-1}\right)$ a/nebo pitné vody s vitamínem E (10,5 mg/kus a den). Po 14 dní byly zjišstovány hemaglutinačně inhibiční titry protilátek proti Newcastleské nemoci u opakovaně vakcinovaných (23. den života) brojlerů. Zvířata byla rozdělena do 4 skupin: (1) kontrolní skupina, (2) vitamín E v pitné vodě, (3) krmení kontaminované toxinem T-2, (4) krmení kontaminované toxinem T-2 v kombinaci s vitamínem E v pitné vodě. Vzorky krve byly odebrány 7. a 14. den experimentu za účelem určení titrů protilátek a obsahu vitamínu E v séru. Ve stejných dnech byly též odebrány vzorky z jater za účelem zjištění množství vitamínu E. Bylo zjištěno, že hemaglutinační titry se zvýšily ve srovnání s kontrolní skupinou jak v důsledku suplementace vitamínem E tak nízké dávky toxinu T-2. Současné použití obou látek vykazovalo synergický účinek. Utilizace vitamínu E se snížila v důsledku zkrmování diety kontaminované toxinem $\mathrm{T}-2$ a to zejména $\mathrm{v}$ játrech.

\section{Acknowledgement}

The financial support received from the Hungarian Academy of Sciences (Animal Breeding and Animal Hygiene Academy Research Group) is gratefully acknowledged.

\section{References}

ATROSHI F, RIZZO A, WESTERMARCK T, ALI-VEHMAS T 2002: Antioxidant nutrients and mycotoxins. Toxicology 180: 151-167

BALLA L 1986: Use of standardized haemagglutination inhibition (HI) test for checking the immunity against Newcastle disease. I. Experiments to standardize the HI test (In Hungarian). Magy Allatorv Lapja 41: 98-103

BENDICH A 1987: Role of antioxidant vitamins on immune function. In Symposium Proceedings "The Role of Vitamins on Animal Performance and Immune Response". RCD 7442. Hoffman-La Roche Inc., Nutley, pp. $17-33$ 
BURMEISTER HR 1971: T-2 toxin production by Fusarium tricinctum on solid substrate. Appl Microbiol 21: 739-742

BÖHM J 2000: Fusariotoxins and their importance in animal nutrition. (Fusarientoxine und ihre Bedeutung in der Tierernahrung). Übers Tierernahr 28: 95-132

DVORSKA JE, SURAI PF 2001: Effects of T-2 toxin, zeolite and Mycosorb on antioxidant systems of growing quail. Asian Aust J Anim Sci 14: 1-6

ERIKSEN GS, PETTERSSON H 2004: Toxicological evaluation of trichothecenes in animal feed. Anim Feed Sci Technol 114: 205-239

GOLUB MS, GERSHWIN ME 1985: Stress-induced immunomodulation: what is it, if it is? In: MOBERG GP (Ed.): Animal Stress. Am J Physiol Soc Bethesda, MD, pp. 177-192

HOSSAIN MI, GUPTA RKP, BHATIA KC, MISHRA UK 1987: Haemagglutination inhibition titres to Newcastle disease virus in T-2 mycotoxin administered chicks. Bangladesh Vet J 21: 99-102

LAFARGE-FRAYSSINET C, DECLOITRE F, MOUSSET S, MARTIN M, FRAYSSINET C 1981: Induction of DNA single-strand breaks by T-2 toxin, a trichothecene metabolite of Fusarium: effect on lymphoid organs and liver. Mutat Res 88: 115-123

LAFARGE-FRAYSSINET C, CHAKOR K, LAFONT P, FRAYSSINET C. 1990: Trans-placental transfer of T-2 toxin: pathological effect. J Environ Pathol Toxicol Oncol 10: 64-68

LEESON S, DIAZ G, SUMMERS JD 1995: Trichothecenes. In: LEESON S, DIAZ G, SUMMERS JD: Poultry metabolic disorders and mycotoxins. University Books, Guelph, pp. 190-226

MCMURRAY CH, BLANCHFLOWER WJ, RICE DA 1980: Influence of extraction techniques on the determination of $\alpha$-tocopherol in animal feedstuffs. J Assoc Off Anal Chem 63: 1258-1261

MÉZES M, BARTA M, NAGY G 1999: Comparative investigation on the effect of T-2 mycotoxin on lipid peroxidation and antioxidant status in different poultry species. Res Vet Sci 66: 19-23

PESTKA JJ, BONDY GS 1994: Immunotoxic effects of mycotoxins. In: MILLER JD, TRENHOLM HL (Eds): Mycotoxins in Grain. Eagen Press, St Paul. pp. 339-358

SKLAN D, KLIPPER E, FRIEDMAN A, SHELLY M, MAKOVSKY B 2001: The effect of chronic feeding of diacetoxyscirpenol, T-2 toxin, and aflatoxin on performance, health and antibody production in chicks. J Appl Poult Res 10: 79-85

SKLAN D, SHELLY M, MAKOVSKY B, GEYRA A, KLIPPER E, FRIEDMAN A 2003: The effect of chronic feeding of diacetoxyscirpenol and T-2 toxin on performance, health, small intestinal physiology and antibody production in turkey poults. Br Poult Sci 44: 46-52

SURAI PF, DVORSKA JE, SPARKS NHC 2004: Natural antioxidants and mycotoxins: theoretical considerations and practical applications. In: ACAMOVIC T, STEWART CS, PENNYCOTT TW (Eds.): Poisonous Plants and Related Toxins. CABI Publishing, Wallingford, pp. 494-503

TENGERDY RP 1989: Vitamin E, immune response and disease resistance. Ann NY Acad Sci 570: 335-344

UENO Y, NAKAJIMA M, SAKAI K, ISHII K, SATO N 1973: Comparative toxicity of trichothecene mycotoxins: inhibition of protein synthesis in animal cells. J Biochem 74: 285-296

RAJU MVLN, DEVEGOWDA G 2002: Esterified-glucomannan in broiler chicken diets contaminated with aflatoxin, ochratoxin and T-2 toxin: evaluation of its binding ability (in vitro) and efficacy as immunomodulator. Asian Aust J Anim Sci 15: 1051-1056

RICHARD JL, CYSEWSKI SJ, PIER AC, BOOTH GD 1978: Comparison of effects of dietary T-2 toxin on growth, immunogenic organs, antibody formation, and pathologic changes in turkeys and chickens. Am J Vet Res 39: 1674-1679

WEBER M, FODOR J, BALOGH K, ERDÉLYI M, MÉZES M 2006a: Dose-dependent effect of T-2 toxin on the immunity against Newcastle disease virus in chickens. Acta Vet Brno 75: 387-391

WEBER M, BALOGH K, ERDÉLYI M, MÉZES M 2006b: Effect of T-2 toxin in combination with vitamin E, selenium and mycotoxin binder on lipid peroxide status and on the glutathione redox system in broiler chicken. J Poult Sci 43: 222-227

WEBER M, STILLER S, BALOGH K, WÁGNER L, ERDÉLYI M, MÉZES M 2007: Effect of feeding T-2 toxin contaminated feed on the utilization of vitamin E in chickens. Acta Vet Hung 55: 21-27 
